> Gi respons på artikler gjennom artiklenes kommentarfelt på tidsskriftet.no.

Innleggene publiseres fortløpende på Tidsskriftets nettside og et utvalg

av innleggene publiseres også i papirutgaven i spalten «Brev til redaktøren».

Redaksjonen forbeholder seg retten til å foreta redaksjonelle endringer.

Forfattere av vitenskapelige artikler har tilsvarsrett, jf. Vancouver-gruppens regler.

\section{Re: Elektronisk tilgang til psykiatrisk journal for pasienter}

Jeanette Bjørke-Bertheussen \& Melissa Weibell skrev i Tidsskriftet nr. 18/2016 en kronikk om elektronisk tilgang til psykiatrisk journal for pasienter (1). Jeg kjenner ikke igjen løsningen slik den presenteres i artikkelen. Kan det være mulig at beskrivelsen av løsningen ikke er oppdatert etter at artikkelen først ble forfattet i april? Siden den gang har voksenpsykiatri-, rus-, og BUP-miljøene vært representert ved ledere i en arbeidsgruppe som har tilpasset løsningen, for nettopp å imøtekomme endel av bekymringene artikkelen tar opp. Miljøene har så utviklet og kvalitetssikret retningslinjer og opplæringsmateriale.

Angående Danmark viser forfatterne til en artikkel fra 2009 som omhandler åpen sykehusjournal på nett. Siden den gang er løsningen endret fra 14 dager til 3-5 dager før pasientene får innsyn (2).

\section{Eva Cathrine Backer}

eva.cathrine.backer@helse-vest-ikt.no

Eva Cathrine Backer (f. 1974) er spesialkonsulent i Helse Vest IKT. Ingen oppgitte interessekonflikter.

\section{Litteratur}

1. Bjørke-Bertheussen J, Weibell M. Elektronisk tilgang til psykiatrisk journal for pasienter. Tidsskr Nor Legeforen 2016; 136: 1562-3.

2. Om Journal fra sygehus. https://www.sundhed.dk/borger/service/hjaelp/ hjaelp-borger/om-mine-sundhedsdata/om-journal-fra-sygehus/ (17.10.2016).

\section{J. Bjørke-Bertheussen \& M.A. Weibell svarer:}

Vi takker Eva Cathrine Backer for kommentaren til vår kronikk (1). Det er riktig at det har gått en tid mellom innsendelse og publikasjon av artikkelen og at noe er blitt endret siden da. Det er blitt avklart at elektronisk tilgang til journal er et servicetilbud, og ikke måten pasienter utøver sin lovhjemlede rett til journalinnsyn. Kriteriene for å sperre dokumenter elektronisk er derfor utvidet utover de snevre unntakene nevnt i Pasient- og brukerrettighetsloven $\S 5-1$. Det er mulig å sperre dokumenter hvis det er nødvendig å gi informasjon direkte til pasienten på en hensynsfull måte før den vises elektronisk, og hvis pasientens tilstand er uavklart og direkte visning på nett vil skape forvirring eller betydelig uro hos pasienten. Disse to alternativene er samlet i begrepet «Utsatt elektronisk visning av hensyn til forsvarlig pasientbehandling».

Sperring kan også utføres ved helt spesielle situasjoner hvor pasienten har fremsatt alvorlige trusler og fremstår aggressiv overfor behandler. Det legges en del føringer for gjennomføring av sperring basert på sistnevnte begrunnelse, inkludert at det «skal drøftes i fagmiljøet og med ansvarlig ledelse» (sitat Stavanger universitetssjukehus, e-læringskurs om Pasienttilgang til journalen). Vi mener at ivaretagelse av personalets HMS må veie tungt, og rutiner og prosedyrer må ikke stå i veien for iverksetting av akutte vurderinger som har med liv og helse å gjøre.

Viktige bekymringer det fortsatt ikke er tatt stilling til, er hvem som kan oppheve sperringer. Ettersom terskelen for å sperre dokumenter er såpass høy har vi gjentatte ganger stilt spørsmål ved hvordan rutinene skal være for hvem som vurderer og åpner sperren. Er det den som har sperret dokumentet? Er det turnuslegen på post? Skal det være spesialist? Vi har ennå ikke fått noe klart svar på hva prosjektledelsen tenker om dette.

Et annet viktig poeng er hvordan særskilt sårbare pasienter ivaretas når de leser journalen alene. Prosjektledelsen har til oss gitt inn- trykk av at situasjonen for de med for eksempel demens eller lærevansker er like utsatte med dagens system der pasient kan be om utskrift av journal skriftlig. Dette er vi uenige i. Umiddelbar tilgang elektronisk åpner for betydelig enklere tilgang som jo er ett av hovedmålene med prosjektet. Men det kan medføre nye problemstillinger, fordi man ikke vet hvilke pasienter som har lest journalen på nett, og derfor ikke lenger kan tilby konsultasjon for å gå gjennom journal sammen med pasienten. I tillegg kan umiddelbar tilgang potensielt gjøre det lettere for andre urettmessig å tilegne seg tilgang til journalen til sårbare pasientgrupper.

Ledelsen ved de ulike psykiatridivisjonene har deltatt $i$ arbeidsgruppen. Som tillitsvalgte for Overlegeforeningen i voksenpsykiatrien har vi imidlertid ønsket å involvere oss sterkere enn kun å komme med innspill per e-post $i$ en prosess vi opplevde hadde uforholdsmessig korte tidsfrister. Vi ba gjentatte ganger om å få delta i gruppen uten at det ble etterkommet.

Oppsummert opplever vi at flere av de bekymringer vi ytrer i kronikken står ved lag, og vi frykter at prosjektet kommer til å gå på bekostning av faglig kommunikasjon og god pasientbehandling.

\section{Jeanette Bjørke-Bertheussen \\ bjje@sus.no \\ Melissa Authén Weibell}

Jeanette Bjørke-Bertheussen (f. 1980) er spesialist i psykiatri og jobber ved Psykiatrisk klinikk, Stavanger universitetssjukehus. Hun er varaforetakstillitsvalgt og varadivisjonstillitsvalgt for Overlegeforeningen, Helse Stavanger.

Ingen oppgitte interessekonflikter

Melissa Authén Weibell (f. 1979) er spesialist i psykiatri og varaforetakstillitsvalgt og divisjonstillitsvalgt ved Psykiatrisk divisjon for Overlegeforeningen, Helse Stavanger. Hun deler arbeidshverdagen sin mellom tillitsvalgtverv, akuttmottaksposten og arbeid med ph.d.-grad. Ingen oppgitte interessekonflikter.

\section{Litteratur}

1. Bjørke-Bertheussen J, Weibell MA. Elektronisk tilgang til psykiatrisk journal for pasienter. Tidsskr Nor Legeforen 2016; 136: 1562-3

\section{Re: Balansekunst}

«Vi må ta mange hensyn dersom vi ønsker at fremtidens legestand skal avspeile biologisk og kulturelt mangfold», skriver assisterende sjefredaktør Ragnhild Ørstavik på lederplass i Tidsskriftet nr. 18/ 2016 (1). Dette er et godt poeng som Legeforeningen bør se som sin fremste oppgave å sikre for befolkningen. Dessverre er det mange pasientgrupper som ikke verdsetter mangfoldet i legestanden, og kanskje spesielt fastlegestanden. Under debatten om reservasjon for fastleger for et par år siden gjorde Legeforeningen lite for å forsvare de legene som hevdet å praktisere sin mulighet for reservasjon i spørsmål om legeetikk innen livsvern. I mange land vi ønsker å sammenligne oss med, er dette en selvfølgelig rettighet, også i det profesjonelle liv. Både USA og Nederland har ordninger for fritt legevalg som sikrer pasientrettigheter uten å tvinge enkeltleger til å følge offentlig vedtatt etikk.

Fastlegeordningen i Norge er i prinsippet også en slik ordning. Likevel ble et mindretall leger presset til å søke andre jobber som 
følge av folkelig motstand mot mangfold, og Legeforeningen så seg ikke i stand til å svare konstruktivt slik Tidsskriftet her gjør. Etter min mening får man dermed den fastlegestanden man fortjener, en legestand med homogene livssyn og ensrettet praksis. Det finnes pasienter der ute som beklager en slik utvikling.

Gunnar Grøstad Johnson

gunnar.g.johnson@vinje.kommune.no

Gunnar Grøstad Johnson (f. 1970) er tilsynslege.

Ingen oppgitte interessekonflikter.

Litteratur

1. Ørstavik RE. Balansekunst. Tidsskr Nor Legeforen 2016; 136: 1503

\section{Re: En kvinne med nevrofibromatose, infeksjonstegn og blødninger}

Takk til Kildahl-Andersen og medarbeidere for en flott kasuistikk i Tidsskriftet (1). Artikkelen er godt skrevet og faglig spennende. Likevel merket jeg meg følgende avsnitt: «Gastrokirurgene ønsket overflytting til revmatologisk avdeling og pasienten ble overført til lungemedisinsk avdeling i påvente av dette. Valg av lungeavdelingen som oppholdssted var tilfeldig.») Er dette god håndtering av en alvorlig syk pasient med uavklart diagnose? Dessverre vil nok flere kjenne til lignende problemstillinger omkring pasientflyt i en presset sykehushverdag.

\section{Øyvind Bruserud}

oyvind.bruserud@uib.no

Øyvind Bruserud (f. 1985) er lege og ph.d.-stipendiat ved Klinisk institutt 2, Universitetet i Bergen.

Ingen oppgitte interessekonflikter.
Litteratur

1. Kildahl-Andersen A, Thoresen M, Thomsen RS et al. En kvinne med nevrofibromatose, infeksjonstegn og blødninger. Tidsskr Nor Legeforen 2016; 136: 1549-52.

\section{Re: Peroral behandling av vitamin $\mathrm{B}_{12}$-mangel}

Undertegnede er nylig blitt gjort oppmerksom på Jon Haffners viktige og gode artikkel om peroral administrasjon av vitamin $\mathrm{B}_{12}(1)$. I Norge opereres omtrent 3000 personer årlig for sykelig overvekt, og et grovt anslag tilsier at minst 20000 nordmenn har gjennomgått en vektreduserende operasjon siden 2004. De aller fleste av disse (> 20000$)$ pasientene må substitusjonsbehandles med vitamin $\mathrm{B}_{12}$ resten av livet, og siden det ikke finnes peroralt vitamin $\mathrm{B}_{12}$ på det norske markedet må vitaminet administreres intramuskulært. Mange av våre pasienter spør naturligvis også hvorfor vitamin $\mathrm{B}_{12}$ må settes som sprøyte flere ganger i året i Norge når det ikke er nødvendig $i$ andre land vi vanligvis sammenligner oss med. Internasjonale retningslinjer åpner også for peroral substitusjonsbehandling med vitamin $\mathrm{B}_{12}$ etter vektreduserende kirurgi dersom det er tilstrekkelig til å forebygge $\mathrm{B}_{12}$-mangel. Hvem kan hjelpe våre pasienter og oss med å få vitamin $\mathrm{B}_{12}$ til peroralt bruk på det norske markedet?

\section{Jøran Hjelmesæth}

joran.hjelmeseth@siv.no

Jøran Hjelmesæth (f. 1957) er senterleder ved Senter for sykelig overvekt i Helse Sør-Øst, Sykehuset i Vestfold og professor ved Universitetet i Oslo. Ingen oppgitte interessekonflikter.

\section{Litteratur}

1. Haffner J. Peroral behandling av vitamin B12-mangel. Tidsskr Nor Legeforen 2016: 136: 108. 